\title{
Research on rainwater utilization potential and key utilization methods of sponge city in Kaifeng, China
}

\author{
Feng $\mathrm{FENG}^{1,2^{*}}$, Xiaoying $\mathrm{JIN}^{1,2}$, Cui $\mathrm{LIU}^{1,2}$ and Ting $\mathrm{ZHAO}^{1,2}$ \\ ${ }^{1}$ Yellow River Conservancy Technical Institute, No.1 Dongjing Main Street, Kaifeng 475004, Henan, China \\ ${ }^{2}$ Middle and Lower Yellow River Water Resources Utilization Engineering Technology Research Center, No.1 Dongjing Main Street, \\ Kaifeng 475004, Henan, China
}

\begin{abstract}
China is carrying out the construction of sponge city vigorously. It is necessary to estimate the utilization potential of urban rainwater resources in order to ensure the implementation of sponge city planning and construction program. There are some problems in the existing calculation models of rainwater resource utilization potential. In view of these problems, we put forward a reasonable classification system of underlying surface, built a rainwater resource utilization potential calculation model suitable for the construction of sponge city, and applied this model in Kaifeng city, and put forward specific measures for the utilization of urban rainwater chain.
\end{abstract}

\section{Introduction}

There are some problems in the existing calculation models, such as:

(1) The calculation principle is not suitable for urban environment. Xu, X. X.(2000) etc. calculated the rainwater confluence potential based on the rainfall data of the loess plateau[1]. Feng, H. (2001) etc. proposed three kinds of rainwater resource utilization potentials, namely theoretical potential, realizable potential and practical potential, and discussed the calculation principle based on small watershed[2]. However, these studies focus on drinking water and rainwater harvesting irrigation in arid and semi-arid areas and are not fully applicable to urban environment.

(2) More qualitative analysis, less quantitative calculation. In terms of urban rainwater recycling, Song, J. X.(2003)etc. analyzed the necessity, possibility and sustainability of rainwater recycling in Xi 'an[3 4]. Li, Y. J.(2003)etc. analyzed the favorable conditions and utilization ways of rainwater resources in Taiyuan city [5].In terms of the calculation of urban rainwater resource potential, Yu, W.D.(2007)etc. divided urban built-up areas into impermeable areas, green garden areas and water areas[6].Huang, X.F.(2007)etc. calculated the potential of urban rainwater resources based on the principle of water balance[7]. Shen, Y.Q.(2015). used GIS as an auxiliary method to estimate the water resource potential of Xindu district of Chengdu by empirical formula method[8]. These studies focus on the significance and approaches of urban rainwater recycling, but rarely involve quantitative studies.

(3) The classification system of underlying surface is unscientific. When calculating the utilization potential of urban rainwater resources, the urban underlying surface is usually divided into three categories: permeable surface, impermeable surface and water surface, which is not in line with the actual situation of urban underlying surface.

\section{Rainwater utilization potential}

\section{1 rainwater resource utilization potential}

\subsubsection{Underlying surface classification of rainwater}

For the above problems, we proposed an improved model. The classification of urban underlying surface is based on the characteristics of rainwater runoff and infiltration of different types of underlying surface. The result is shown in Fig 1.

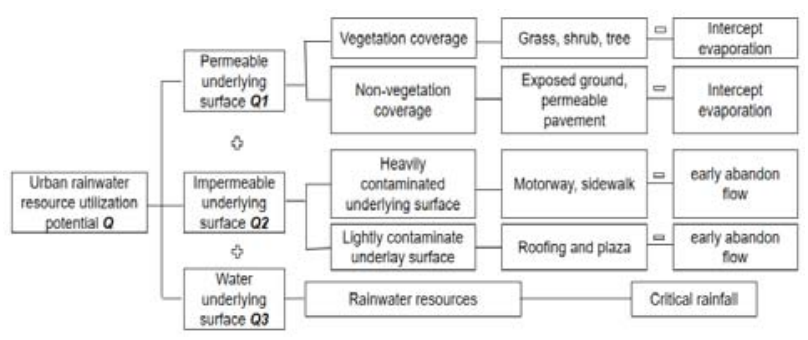

Fig. 1. City underlying surface classification system

\subsubsection{Utilization potential calculation of rainwater resource}

The rainwater that exceeds the maximum capacity of the city is called critical precipitation, which is not within the calculation range. Urban rainwater resource

\footnotetext{
* Corresponding author: fengfeng@yrcti.edu.cn
} 
utilization potential $Q$ is composed of three parts, including impermeable underlying surface rainwater resource utilization potential $Q_{1}$, permeable underlying surface rainwater resource utilization potential $Q_{2}$, and water underlying surface rainwater resource utilization potential $Q_{3}$.

$$
\begin{gathered}
Q_{1}=\sum_{i=1}^{m}\left(R_{i}-R_{k}\right) \times S_{1} \times 1000 \\
Q_{2}=\sum_{i=1}^{m}\left(R_{i}-R_{a}\right) \times S_{2} \times 1000 \\
Q_{3}=R \times S_{3} \times 1000 \\
Q_{t}=\sum_{i=1}^{m}\left(R_{i}-\mathrm{r}_{a}\right) \times S \times 1000
\end{gathered}
$$

Formula for calculating the theoretical utilization potential:

$$
Q_{s}=Q_{1}+Q_{2}+Q_{3}
$$

Formula for calculating the realizable utilization potential:

$$
Q_{e}=Q_{s}-Q_{t}
$$

$R_{i}$ process rainfall, $\mathrm{mm}$;

$R_{k} \longrightarrow$ precipitation loss and the initial abandoned flow, urban impermeable underlying surface can be taken 4 6mm;

$m —$ precipitation times in a certain period, such as 1 year;

$R_{a} \longrightarrow$ vegetation interception, $0.3 \mathrm{~mm}$;

$r_{a} \_$critical rainfall, the maximum amount a city can hold in a single rainfall, $50 \mathrm{~mm}$;

$R$ - total precipitation for a period of time, $\mathrm{mm}$;

$S_{l}$ _-impermeable underlying surface, $\mathrm{km}^{2}$;

$S_{2}$ permeable underlying surface, $\mathrm{km}^{2}$;

$S_{3}-$ water underlying surface, $\mathrm{km}^{2}$;

$\mathrm{S}=S_{I}+S_{2}+S_{3}, \mathrm{~km}^{2}$ 。

\section{Analysis on utilization potential of rainwater resources in Kaifeng City}

\subsection{Overview of the research area}

\subsubsection{Nature overview}

Kaifeng city is located in the east of Henan Province, located in the south bank of the lower Yellow Rive. The landform is part of the alluvial fan plain in the lower Yellow River. The terrain is flat, the general trend of the landform is slightly inclined from the northwest to the southeast, the surface slope drops to $1 / 2000 \sim 1 / 4000$, and the altitude is between $69 \sim 78 \mathrm{~m}$. The average annual precipitation in this area is $662.8 \mathrm{~mm}$, and the rainfall in
July and August accounts for more than $65 \%$ of the annual precipitation. The average annual evaporation is 1 $600 \sim 2000 \mathrm{~mm}$, among which the evaporation in May and June is the largest, accounting for $25 \% \sim 30 \%$ of the annual evaporation. The main recharge methods of shallow groundwater are meteoric precipitation infiltration, lateral infiltration of the Yellow River, canal leakage, irrigation return infiltration, etc. The groundwater flow is consistent with the slope of the terrain, and the drainage methods are mainly mining and evaporation. Kaifeng city is dotted with lakes and ponds, the total amount of water storage 4.1 million $\mathrm{m}^{3}$, so it is known as the "northern water city".

\subsubsection{Water resources}

The local water resources of Kaifeng City are far from meeting the demand of water quantity and quality for the city's economic and social development, so the city has been relying on the water from the Yellow River for a long time. The region's water deficit. With the acceleration of economic and social development and urbanization, the urban water consumption continues to increase, and the sewage discharge continues to increase, and the contradiction between the supply and demand of water resources becomes more prominent. The supply of surface water is very limited, the total amount of yellow water is strictly controlled, and the groundwater cannot be over-exploited. Therefore, making full use of urban rainwater resources is an economical, quick and widely effective way. Rainwater recycling can not only solve the urban water resources crisis, but also bring a series of ecological environmental effects such as groundwater conservation, alleviation and recovery of land subsidence, climate regulation, air purification, strengthening urban greening, improving urban environment, changing urban drainage system, prevention and control of rain and flood.

\subsection{Utilization potential of rainwater resources in Kaifeng City}

\subsubsection{Interpretation and calculation}

By interpreting HD images(as shown in Fig.2), we obtained the land cover data of $144.6 \mathrm{~km}^{2}$ urban built-up area in Kaifeng from 2013 to 2017 (as shown in Table 1). The annual total runoff control rate of Kaifeng is targeted at $75 \% \sim 85 \%[9]$. According to the lower limit of control rate, we applied the model to Kaifeng and obtained relevant data (as shown in Table 2). $R_{k}=6 \mathrm{~mm}$, $R_{a}=0.3 \mathrm{~mm}, r_{a}=50 \mathrm{~mm}$. 


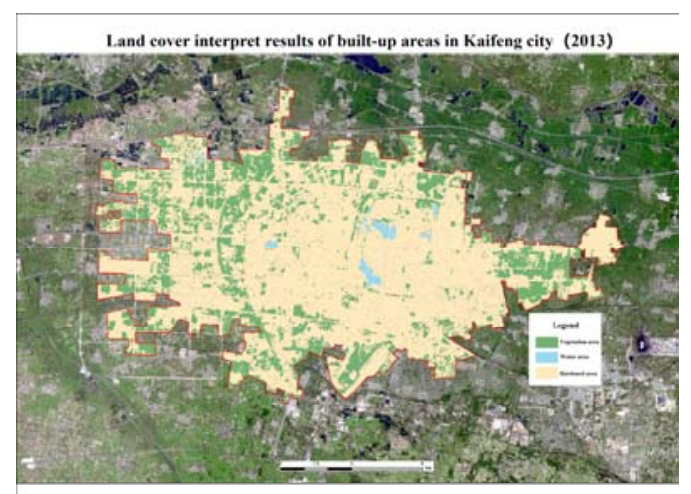

Land cover interpret results of built-up areas in Kaifeng eity (2014)
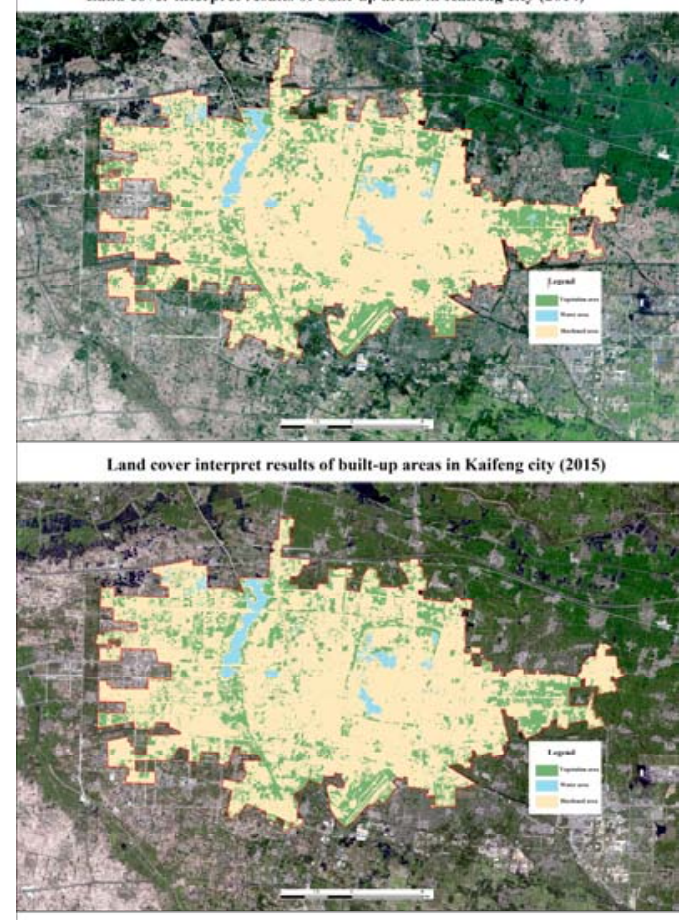

Land cover interpret results of built-up areas in Kaifeng eity (2016)

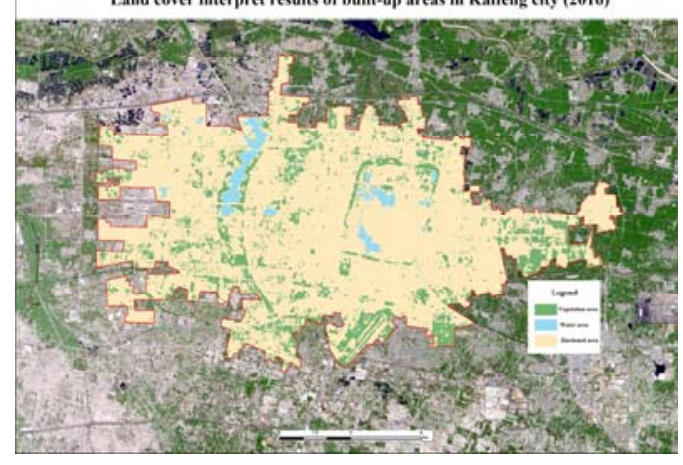

Land eaver interpret results of built-up areas in Kaifeng eity (2017)

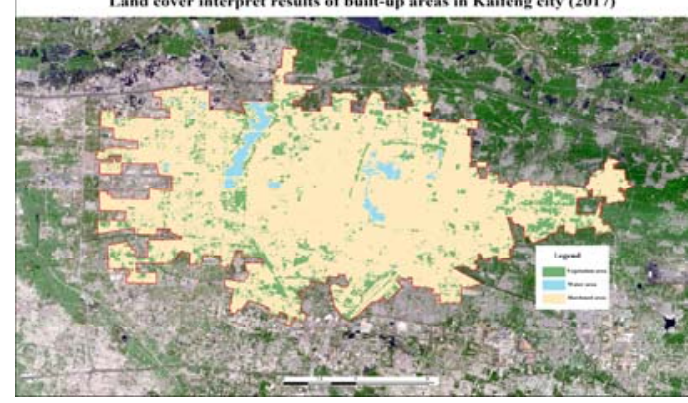

Fig. 2.High definition satellite image of land vegetation cover in Kaifeng from 2013 to 2017.

Table 1 Land cover interpret results of built-up areas in Kaifeng city (2013-2017)

\begin{tabular}{|c|c|c|c|c|}
\hline Year & $\begin{array}{c}\text { Hardened } \\
\text { area } \\
\mathbf{/ k m}\end{array}$ & $\begin{array}{c}\text { Vegetation } \\
\text { area } \\
/ \mathbf{k m}^{2}\end{array}$ & $\begin{array}{c}\text { Water area } \\
/ \mathbf{k m}^{2}\end{array}$ & $\begin{array}{c}\text { Total } \\
\mathbf{k m}^{2}\end{array}$ \\
\hline 2013 & 104.49 & 38.55 & 1.56 & 144.60 \\
\hline 2014 & 106.62 & 33.75 & 4.23 & 144.60 \\
\hline 2015 & 108.37 & 32.35 & 3.88 & 144.60 \\
\hline 2016 & 116.31 & 24.34 & 3.95 & 144.60 \\
\hline 2017 & 119.86 & 20.93 & 3.81 & 144.60 \\
\hline
\end{tabular}

Table 2 Rainwater resource utilization potential calculation results in Kaifeng city

\begin{tabular}{|c|c|c|c|c|}
\hline Year & $\begin{array}{l}\text { Annual } \\
\text { rainfall } \\
\mathbf{R} / \mathbf{m m}\end{array}$ & $\begin{array}{c}\text { Impermeable } \\
\text { underlying } \\
\text { surface } \\
\mathbf{Q}_{1} / \mathbf{m}^{3} \times 1^{6}\end{array}$ & $\begin{array}{c}\text { Permeable } \\
\text { underlying } \\
\text { surface } \\
\mathbf{Q}_{2} / \mathbf{m}^{3} \times \\
\mathbf{1 0}^{6} \\
\end{array}$ & $\begin{array}{c}\text { Water } \\
\text { underlying } \\
\text { surface } \\
\mathbf{Q}_{3} / \mathbf{m}^{3} \times \\
\mathbf{1 0}^{6} \\
\end{array}$ \\
\hline 2013 & 409.7 & 25.192539 & 15.296640 & 0.639132 \\
\hline 2014 & 645.2 & 41.187306 & 21.078563 & 2.729196 \\
\hline 2015 & 764.8 & 43.402185 & 23.786955 & 2.967424 \\
\hline 2016 & 424.3 & 27.542208 & 9.810643 & 1.676117 \\
\hline 2017 & 529.6 & 35.538490 & 10.714067 & 2.017776 \\
\hline Year & \begin{tabular}{|c|} 
Theoretical \\
utilization \\
potential \\
$\mathbf{Q}_{\mathbf{s}} / \mathbf{m}^{3} \times 10^{6}$ \\
\end{tabular} & $\begin{array}{c}\text { Critical } \\
\text { rainfall } \\
\mathbf{Q}_{\mathrm{t}} / \mathbf{m}^{3} \times 10^{6}\end{array}$ & $\begin{array}{c}\text { Realizable } \\
\text { utilization } \\
\text { potential } \\
\mathbf{Q}_{\mathrm{e}} / \mathbf{m}^{3} \times \mathbf{1 0}^{6} \\
\end{array}$ & $\begin{array}{c}\begin{array}{c}\text { Utilization } \\
\text { target }\end{array} \\
\mathbf{Q} / \mathbf{m}^{3} \times 10^{6} \\
\end{array}$ \\
\hline 2013 & 41.128311 & 4.005420 & 37.122891 & 27.842168 \\
\hline 2014 & 64.995065 & 3.181200 & 61.813865 & 46.360399 \\
\hline 2015 & 70.156564 & 0.000000 & 70.156564 & 52.617423 \\
\hline 2016 & 39.028967 & 0.000000 & 39.028967 & 29.271725 \\
\hline 2017 & 48.270333 & 4.077720 & 44.192613 & 33.144460 \\
\hline
\end{tabular}




\section{Rainwater key utilization methods of sponge city}

\subsection{Optimization measures of urban underlay surface}

According to the law of annual variation of urban rainwater utilization potential and its relationship with underlying surface, the optimization measures of different types of underlying surface are put forward. Such as through Water surface can be used to increase the vegetation coverage, the construction of sunken green space, grass gully, rain garden, etc., to increase the space of rainwater infiltration, the formation of rainwater retention, in the slow process of infiltration, rainwater purification. Impermeable cushion surface can use green roof, green wall, balcony garden and other ways of stagnant storage or purification of rainwater, or in the residential area, the city road and other suitable location to set up underground storage module. Under the water area cushion surface can pay attention to artificial wetland, ecological embankment, ecological floating island, urban landscape sponge cell construction. All rainwater collected can be used in the dry season or the season when water is needed for maintenance of green plants, road cleaning, vehicle washing, urban landscape water body construction, etc., in order to complete the "sponge water release". The sponge cell design for storm water management and utilization of the roof and impermeable hardened floor is shown in Table 3 and Table 4.

Table 3 Roof rainwater management and utilization cell design

\begin{tabular}{|c|c|c|c|c|c|}
\hline Methods & $\begin{array}{l}\text { Facilitie } \\
\qquad \mathrm{s}\end{array}$ & $\begin{array}{c}\text { Singl } \\
\text { e- } \\
\text { famil } \\
y \\
\text { home } \\
\text { s } \\
\end{array}$ & $\begin{array}{l}\text { Multi- } \\
\text { storey, } \\
\text { high-rise } \\
\text { residenti } \\
\quad \text { al }\end{array}$ & $\begin{array}{c}\text { Public } \\
\text { buildin } \\
\text { gs }\end{array}$ & $\begin{array}{c}\text { Larg } \\
\text { e } \\
\text { roof }\end{array}$ \\
\hline \multirow{5}{*}{$\begin{array}{l}\text { Collectio } \\
\mathrm{n} \\
\text { and } \\
\text { recycling }\end{array}$} & $\begin{array}{c}\text { Above- } \\
\text { ground } \\
\text { water } \\
\text { storage } \\
\text { tanks }\end{array}$ & $\bullet$ & (0) & (?) & ० \\
\hline & $\begin{array}{c}\text { Wet } \\
\text { pond, } \\
\text { landscap } \\
\text { e water } \\
\text { body }\end{array}$ & $\bullet$ & $\bullet$ & $\bullet$ & $\bullet$ \\
\hline & $\begin{array}{c}\text { Reservoi } \\
\mathrm{r}\end{array}$ & ○ & (-) & $\bullet$ & $\bullet$ \\
\hline & $\begin{array}{c}\text { Ditch } \\
\text { transfer }\end{array}$ & () & $\bullet$ & $\bullet$ & $\bullet$ \\
\hline & $\begin{array}{l}\text { Abandon } \\
\text { flow }+ \\
\text { pipeline } \\
\text { transfer }\end{array}$ & ( ) & (-) & () & (2) \\
\hline \multirow{2}{*}{$\begin{array}{l}\text { Infiltrati } \\
\text { on }\end{array}$} & $\begin{array}{c}\text { Breakout } \\
\text { emission } \\
\mathrm{s} \\
\end{array}$ & ○) & $\bullet$ & $\bullet$ & $\bullet$ \\
\hline & $\begin{array}{l}\text { Ecologic } \\
\text { al water } \\
\text { infiltrati }\end{array}$ & () & $\bullet$ & $\bullet$ & $\bullet$ \\
\hline
\end{tabular}

\begin{tabular}{|c|c|c|c|c|c|}
\hline & on & & & & \\
\hline & $\begin{array}{c}\text { Buried } \\
\text { infiltrati } \\
\text { on }\end{array}$ & 0 & 0 & (?) & () \\
\hline \multirow{2}{*}{$\begin{array}{c}\text { Regulati } \\
\text { on and } \\
\text { discharg } \\
\mathrm{e}\end{array}$} & $\begin{array}{c}\text { Wet } \\
\text { pond, } \\
\text { landscap } \\
\text { e water } \\
\text { body }\end{array}$ & 0 & $\bullet$ & • & $\bullet$ \\
\hline & $\begin{array}{c}\text { Buried } \\
\text { storage } \\
\text { tank }\end{array}$ & 0 & () & (?) & () \\
\hline
\end{tabular}

Table 4 Watertight hardening ground rainwater management utilization cell design

\begin{tabular}{|c|c|c|c|c|c|c|}
\hline $\begin{array}{c}\text { Metho } \\
\text { ds }\end{array}$ & $\begin{array}{l}\text { Faciliti } \\
\text { es }\end{array}$ & $\begin{array}{l}\text { Court } \\
\text { yard }\end{array}$ & $\begin{array}{l}\text { Pave } \\
\text { ment }\end{array}$ & $\begin{array}{l}\text { Squ } \\
\text { are }\end{array}$ & $\begin{array}{c}\text { Driv } \\
\text { ing } \\
\text { road }\end{array}$ & $\begin{array}{c}\text { Park } \\
\text { ing } \\
\text { lot }\end{array}$ \\
\hline \multirow{11}{*}{$\begin{array}{l}\text { Infiltra } \\
\text { tion }\end{array}$} & $\begin{array}{l}\text { Permea } \\
\text { ble } \\
\text { pavem } \\
\text { ent }\end{array}$ & • & • & • & () & ○) \\
\hline & $\begin{array}{c}\text { Straw } \\
\text { brick } \\
\text { paving }\end{array}$ & • & ( ) & ( ) & (-) & $\bullet$ \\
\hline & $\begin{array}{l}\text { Conca } \\
\text { ve } \\
\text { greenb } \\
\text { elt }\end{array}$ & • & $\bullet$ & $\bullet$ & $\bullet$ & $\bullet$ \\
\hline & $\begin{array}{l}\text { Grasse } \\
\text { d ditch }\end{array}$ & • & • & • & • & • \\
\hline & $\begin{array}{c}\text { Grasse } \\
\text { d } \\
\text { lowlan } \\
\text { d }\end{array}$ & (0) & • & • & • & • \\
\hline & $\begin{array}{l}\text { Biologi } \\
\text { cal } \\
\text { strande } \\
\text { d } \\
\end{array}$ & ๑ & ๑) & • & • & $\bullet$ \\
\hline & $\begin{array}{c}\text { Dry } \\
\text { pond }\end{array}$ & ( ) & • & • & • & • \\
\hline & $\begin{array}{l}\text { Infiltra } \\
\text { tion } \\
\text { trench }\end{array}$ & ○ & () & • & $\circ$ & $\circ$ \\
\hline & $\begin{array}{l}\text { Infiltra } \\
\text { tion } \\
\text { dischar } \\
\text { ge }\end{array}$ & 0 & (-) & • & $\circ$ & $\circ$ \\
\hline & $\begin{array}{l}\text { Penetra } \\
\text { ting } \\
\text { Wells }\end{array}$ & $\circ$ & (-) & (-) & $\circ$ & $\circ$ \\
\hline & $\begin{array}{c}\text { Infiltra } \\
\text { tion } \\
\text { pool }\end{array}$ & ○ & $\circ$ & () & $\circ$ & $\circ$ \\
\hline \multirow{4}{*}{$\begin{array}{l}\text { Collect } \\
\text { ion } \\
\text { and } \\
\text { recycli } \\
\text { ng }\end{array}$} & $\begin{array}{l}\text { Grasse } \\
\text { d ditch } \\
\text { for } \\
\text { water }\end{array}$ & $\bullet$ & • & • & $\circ$ & ० \\
\hline & $\begin{array}{l}\text { Pebble } \\
\text { ditch }\end{array}$ & • & • & • & ๑) & ○ \\
\hline & $\begin{array}{l}\text { Wet } \\
\text { pond, } \\
\text { water } \\
\text { body }\end{array}$ & • & $\bullet$ & • & (-) & o \\
\hline & $\begin{array}{c}\text { Buried } \\
\text { pool }\end{array}$ & ( ) & (-) & ( ) & $\circ$ & $\circ$ \\
\hline
\end{tabular}




\begin{tabular}{|c|c|c|c|c|c|c|}
\hline & $(\operatorname{tank})$ & & & & & \\
\hline \multirow{2}{*}{$\begin{array}{l}\text { Regula } \\
\text { tion } \\
\text { and } \\
\text { dischar } \\
\text { ge }\end{array}$} & $\begin{array}{l}\text { Wet } \\
\text { pond, } \\
\text { landsca } \\
\text { pe } \\
\text { water } \\
\text { body }\end{array}$ & 0 & - & - & • & - \\
\hline & $\begin{array}{c}\text { Buried } \\
\text { storage } \\
\text { tank }\end{array}$ & 0 & (?) & (?) & () & () \\
\hline
\end{tabular}

\subsection{Rainwater chain design of sponge city}

Through reasonable design between cells, the runoff path of rainwater is connected to form a rain water chain (as shown in Fig.3), thus forming an urban sponge in harmony with nature.

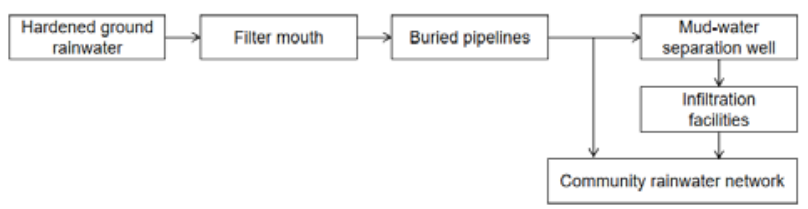

(a) buried infiltration rainwater chain

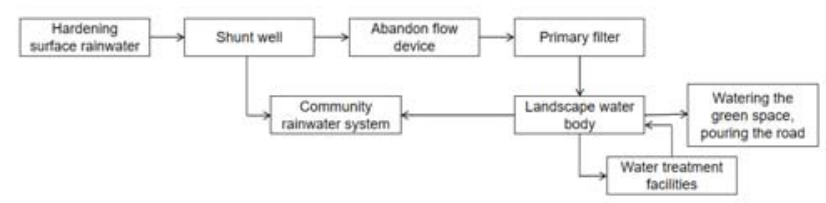

(b) A wet pond or landscape body of water stores a rainwater chain

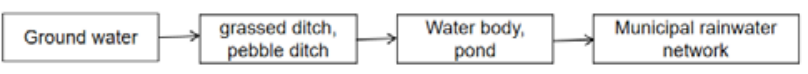

(c) Water body, pit pond regulation rainwater discharge chain

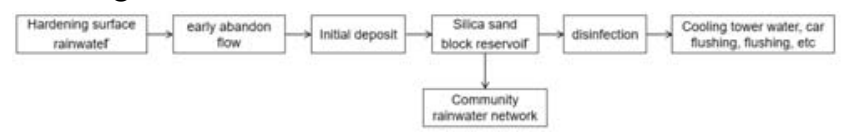

(d) Miscellaneous rainwater chain

Fig.3.Design of sponge city rainwater chain

\section{Conclusions}

Kaifeng has long relied on the Yellow River to make up for its lack of water. The available amount of surface water is very limited, the amount of water diverted from the Yellow River is strictly controlled, and the groundwater cannot be over-exploited. Making full use of urban rainwater resources is an economical, fast and effective way. But, urban construction has its own characteristics, we need to carry out scientific planning according to the objective conditions of the city, gradually promote the construction of sponge city, so as to improve the ecological environment of the city, improve the quality of the city.

\section{References}

1. $\mathrm{Xu}, \mathrm{X} . \mathrm{X}$. and $\mathrm{Mu}, \mathrm{X} . \mathrm{M}$. and Wang, W. L. (2000), Preliminary analysis of rainwater resource recovery potential in loess plateau (part of Shaanxi province). Resource science.22(1):31-34.

2. Feng, H. and Shao, M. G. (2001), Calculation and evaluation of rainwater resources potential in small watershed of loess plateau. Chinese journal of natural resources. 16(2):140-144.

3. Song,J. X. and Li, H. E. and Li, Q.(2003). Urban rainwater recycling and ecological environmental effects. Journal of ecology. 22(2):32-35.

4. Song, J. X. and Li, H. Y. and Wang, B. D(2002). Exploration on rainwater recycling and utilization in $\mathrm{Xi}$ 'an. Chinese journal of soil and water conservation. 16(3):102-105.

5. Li, Y. J. and Gao, X. L. and Yang R. P. (2003), Urban rainwater recycling -- a case study of taiyuan. Land and natural resources research. (1):7-8.

6. Yu, W. D. and Tang, J. H. (2007), Study on the potential of urban rainwater recycling. Meteorology and environmental science. 30(3):29-32.

7. Huang, X. F. and Shao, D. G. and Wei, X. H. (2007), Analysis model of urban rainwater utilization potential based on water balance. Journal of wuhan university: engineering science. 40(2):17-20.

8. Shen, Y. Q. (2015), Analysis of rainwater recycling potential and utilization model in chengdu. $\mathrm{Xi}$ 'an: $\mathrm{Xi}$ 'an university of science and technology.

9. General Office of the State Council. About advancing the sponge guidance for the construction of city . http://www.mof.gov.cn/zhengwuxinxi/zhengcefabu/ 201510/t20151016_1507043.htm. 